\title{
粉末を用いたステンレス刃物用鋼の開発
}

\author{
納富 完至々1，塩浦 時宗约2 \\ 的1 神戸製鋼所鋳鈠鋼事業部技術部開発室, 干676 高砂市荒井町新浜2-3-1. \\ 仿2 的新潟県県央地域地場産業振興センター, 干955 三条市須頃1-17.
}

\section{The New P/M Stainless Steel "PM21" for Cutlery}

\author{
Kanji Notomi ${ }^{\hbar 1}$ and Tokimune Shioura ${ }^{\text {皮2 }}$ \\ t1 Engineering Department, Steel Casting \& Forging Group, Kobe Steel Ltd., 2-3-1 Shinhama Arai-Cho, \\ Takasago 676. 2 Regional Industries Promotion Center of Central Niigata Pref., 1-17 Sugoro, Sanjo 955.
}

Received December 11, 1996

\section{SYNOPSIS}

The new P/M stainless steel called "PM21" for cutlery was produced by the Gas Atomization plusHIP process. The microstructure, mechanical properties, corrosion resistance and cutlery properties of the steel were investigated in comparison with conventionally cast and forged alloy steels and a P/M high speed steel. The studies indicated that PM21 has a lot of carbides and a fine homogeneous carbide structure that confers high toughness and high wear resistance. Additionally, PM21 has a much higher corrosion resistance than that of SUS440C stainless steel. The studies also showed that the cutlery properties of PM21 are far superior to those of conventional steel.

\section{KEY WORDS}

P/M stainless steel, cutlery, sharpness, corrosion resistance.

\section{1 緒 言}

現在刃物用材料として,炭素銅, 合金鎆, ステンレス 鋼などが広く使用されている.ところで,これまでステ ンレス鋼刃物は耐食性に優れているものの, 高い硬さ が得られにくく（58 HRC〜 $60 \mathrm{HRC}$ 程度）炭素 鋼刃物および合金鋼刃物に比べ，切れ味が劣るとされ ていた ${ }^{1,2)}$.

今回著者等は,切れ味性の優れたステンレス刃物鋼 を開発するため，J I S - SUS 440 C鋼の高合金 化と粉末冶金プロセスの活用により，(1)高硬度（62 H R C 以上),(2)高勒性（抗折值： $3000 \mathrm{MP}$ a 以 上), (3)高耐食性 (SUS $440 \mathrm{C}$ 同程度以上) を兼備 した刃物銅を開発し，次いで同龬を用いた刃物の切れ 味試験およびユーザテストにおいて良好な成績を得る ことができたので，以下に報告する．

\section{2 実酫方法}

\section{1 供試材}

ガスアトマイズーH I Pプロセスにより,クロムを $18 \%$ 含む 3 種類のマルテンサイト系ステンレス銅塊 を試作した、次いで,般造一圧延を経て, $13 \mathrm{~mm}$ 厚さ の圧延材を得た.試作材（No1材〜No3 材）の化学 組成を Table 1に示す. 同表より, 試作材はいずれも，S US $440 \mathrm{C}$ C $, \mathrm{C} \mathrm{r}, \mathrm{Mo}$, Vを高合金化した材 料であることがわかる.なお同表には，比較材として使 用した従来溶製法によるSUS $440 \mathrm{C}$ と合金刃物鋼 およびKHA 32 (粉末高速度鎆) の化学組成も併せ て示した。

\section{2 材料試娩}

上述の $13 \mathrm{~mm}$ 圧延材より，Fig.1に示すように, 圧 延方向と平行な方向より試験片を採取した. また, 比較 材からの試験片採取も Fig.1に淮じて行った，次に 
Table 1 Compositions of the tested materials.

\begin{tabular}{|c|c|c|c|c|c|}
\hline Material & C & Cr & Mo & W & V \\
\hline Steel No.1 & 1.55 & 18.1 & 0.48 & - & 2.95 \\
\hline Steel No.2 & 1.62 & 18.2 & 1.96 & - & 3.03 \\
\hline Steel No.3 & 1.31 & 18.2 & 4.02 & - & 1.05 \\
\hline SUS440C & 0.98 & 16.6 & 0.42 & - & - \\
\hline KHA32 & 1.30 & 4.1 & 5.10 & 6.54 & 2.98 \\
\hline Alloy Steel & 1.35 & 0.4 & - & 1.75 & - \\
\hline
\end{tabular}

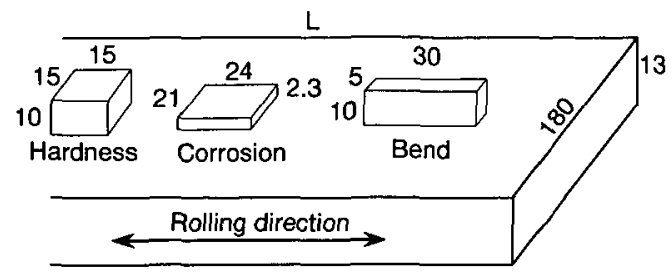

Fig.1 Sampling of specimens.

Table 2に示す熱処理パターンで, 真空熱処理炉とサブ ゼロ装膡を用いて焼入焼もどし処理を実施後, 各種試 験に供した.なお，試作材（No1材〜 No3材）の熱 処理は, 熱処理試験片と抗折試験片以外はすべて, 1 $50^{\circ}$ C焼もどしとした。

\subsection{1 熱処理硬さ}

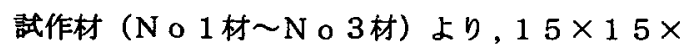
$10 \mathrm{~mm}$ の熱処理試験片を作製 し, Table 2 に示す七一 トパターンで熱好理後, HRC硬さ計にて 5 点繰返し 测定を行い, 平均值を算出した。

Table 2 Heat treatment of specimens.

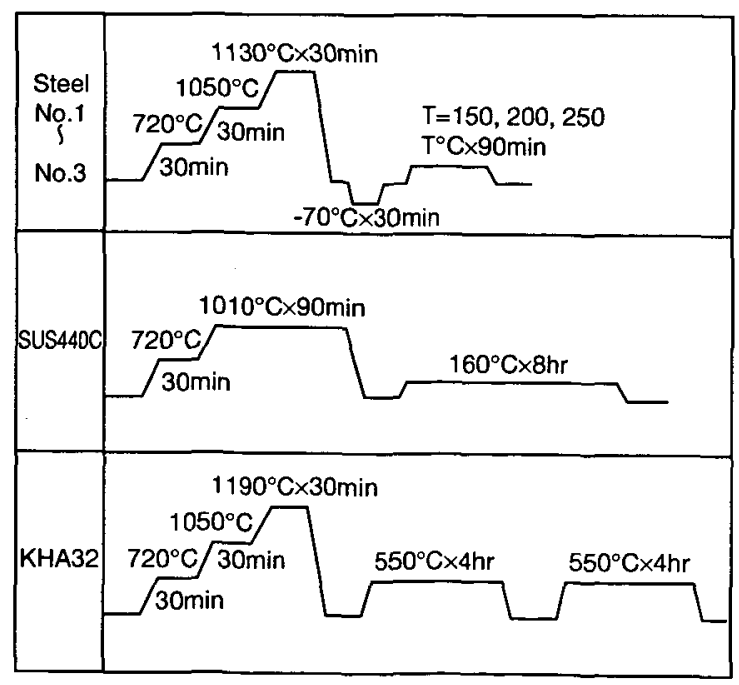

\subsection{2 ミクロ組織観察}

Table 2に示す熱処理を施した後, 光学影微鏡による ミクロ組織観察を実施した. 試作材とSUS $440 \mathrm{C}$ は $1 \%$ C r 酸電解エッチ後,またKHA 32 は村上試 薬でエッチ後，1000倍にて観察した。次いで,画像 処理装置を用いて敌化物の定量測定を行うとともに， X線回折法により炭化物の種類を同定した。

\subsection{3 抗折試験}

$5 \times 10 \times 30 \mathrm{~mm}$ の試騟片を用い, 支点閒距離 2 $0 \mathrm{~mm}$ で 3 点曲げ試験を行い,抗折值を求めた. 繰返し 数は $\mathrm{n}=3$ とした。

\subsection{4 水道水浸清試験}

2. $3 \times 21 \times 24 \mathrm{~mm}$ の試験片を, 乾式研磨にて\# 500 まで仕上げ, 脱脂洗浄後, 静止した水道水中に, 24 時間浸漬し, 錆の発生状況を観察した. 綝返し数は $\mathrm{n}=3$ とした。

\subsection{5 塩水噴霧試験}

2. $3 \times 21 \times 24 \mathrm{~mm}$ の試験片を, 乾式研磨にて\# 500 まで仕上げ,脱脂洗浄後試験に供した.塩水噴䨳 試験は, J I S - Z - 237 1に準じて, $5 \%$ 食塩水で 行った. 7 時間噴霧後,試験片の表面に付着した食塩お よび腐食生成物をブラシ挂けで除去し，錆の発生状况 の観察および質量测定を行った。ついで試験前後の質 量変化より腐食減量を算出した.なお, 練返し数はn= 2 とした。

\section{3 刃物の試作}

上述の $13 \mathrm{~mm}$ 圧延材をさらに圧延, 鍛造して刃物 用素材とし，1130 C焼入れ $150^{\circ}$ C焼もどしの熱 処理条件（Table 2）で,同材を用いて，包丁およびは さみを試作した。なお， $\mathrm{N}$ 。 2 材は鍛造時に割れが発生 したため, 刃物の試作ができなかった。

\subsection{1 切れ味試験 ${ }^{3)}$}

No1材とNo3材を用いて試作したさしみ包丁の 切れ味性を従来品 (C; $1.4 \% \mathrm{Si} ; 0.1 \% \mathrm{Mn} ; 0.2 \% \mathrm{Cr}$; $0.4 \% \mathrm{~W} ; 1.8 \%$ 硬さ；63HRC) と比較した.使用した切 れ味試験機の機構図を Fig.2に示す，切削荷重 (W) を $3 \mathbf{~ k g f}$ 一定とし,カセット内にセットされた上質紙(被 削材) が 1 ストロークで何枚切れるかを繰返し計数し， 切れ味性を評洒した。

\subsection{2 ユーザテスト}

試作したはさみ,包丁を用い,ユーザテストを実施し た. 


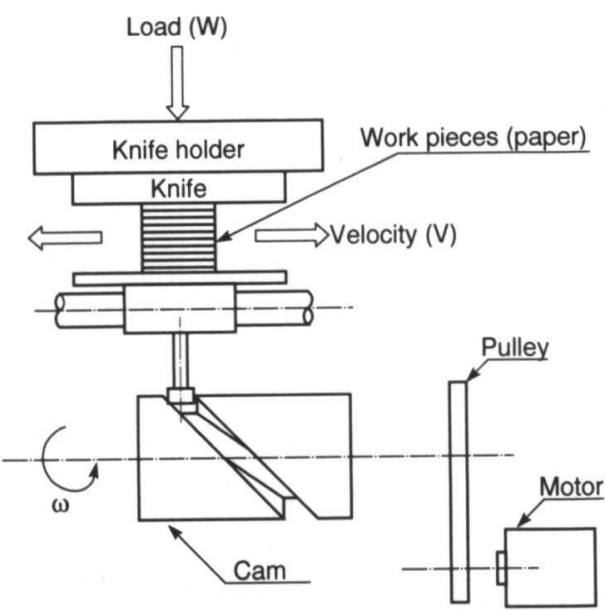

Fig.2 Scheme of the sharpness test.

\section{3 実験結果と考察}

\section{1 材料試験}

\section{1 .1 熱処理硬さ}

試作材の焼入焼もどし硬さを Fig.3に示す. 同図よ り, 試作材は $150^{\circ} \mathrm{C}$ 焼もどし後に, $62 \mathrm{HRC} \sim 6$ 4 HR Cの硬さを有していることがわかる.なかでも, No 3 材の硬さが最も高いことがわかる.

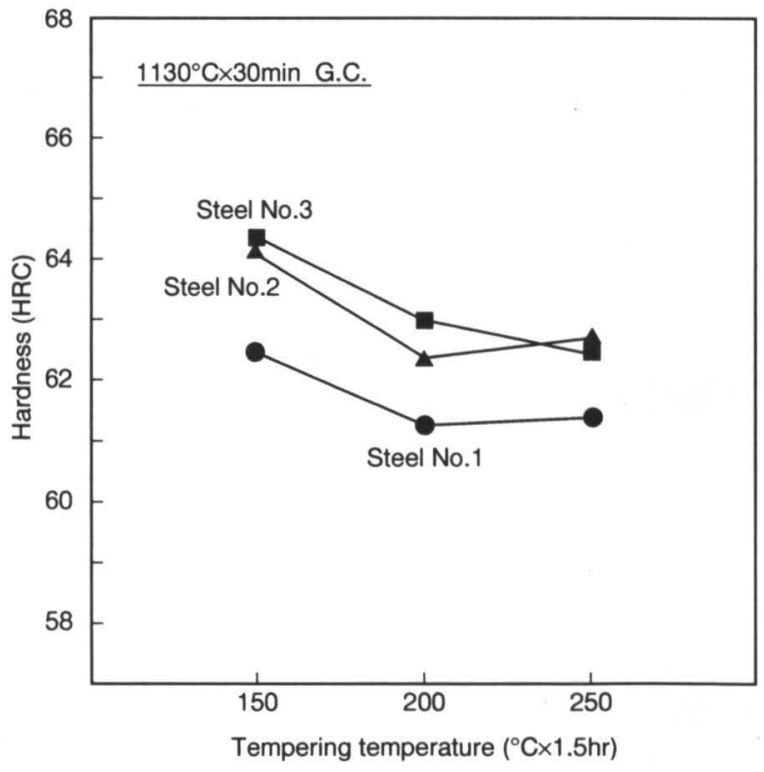

Fig.3 Tempered hadrdness.

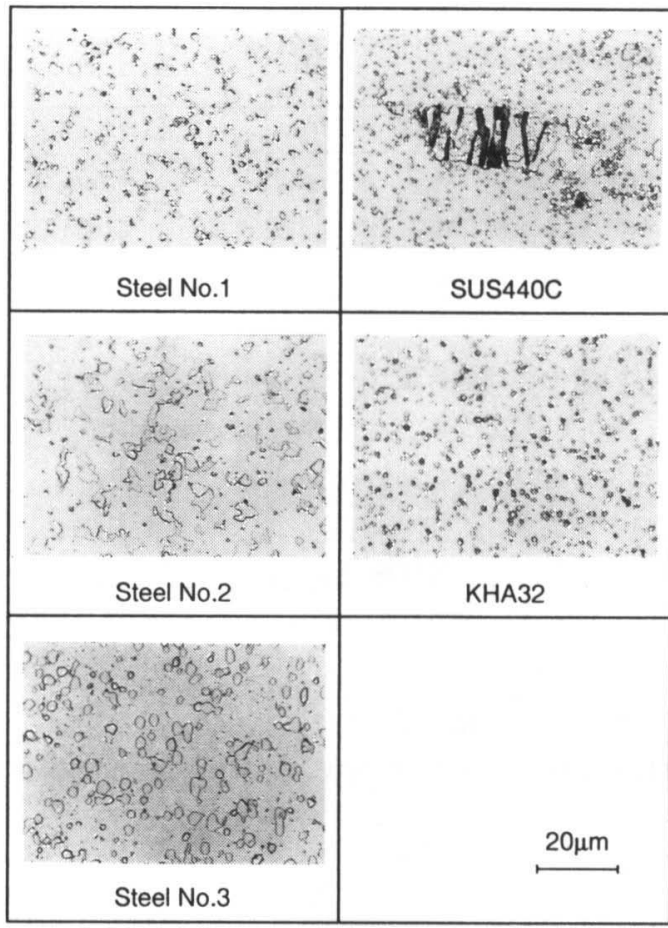

Photo.1 Micrographs of speciments.

\subsection{2 ミクロ組織観察}

供試材の $150^{\circ} \mathrm{C}$ 焼もどし後のミクロ組織をPhoto.1 に示す.試作粉末材はいずれも,均一微細な炭化物組織 を有していることがわかる.炭化物の形状はN o 1 材 と No 3 材は球状であるが, No2材は異形状となっ ている. No 3 材の炭化物は粒径が $1 \sim 4 \mu \mathrm{m}$ で, $\mathrm{N}$ o 1 材に比べ若干大きく, 量も多いようである .

次に比較溶製材 S U S $440 \mathrm{C}$ では, $1 \mu \mathrm{m}$ 程度の 微細な炭化物の間に, 数十 $\mu \mathrm{m}$ におよぶ巨大炭化物の 散在している様子が観察される.また, 巨大炭化物には 圧延時に生じたと思われる無数のクラックも観察され る.これら巨大炭化物は製法上避けがたいもので,これ らが溶製材S U S 440 Cの鞋性を大きく低下させ， 刃先の欠けや刃こぼれの原因になっているものと思わ れる4).

最後はKHA 32 (粉末高速度鋼) の組織で $1 \mu \mathrm{m}$ 前後の微細な炭化物が均一に分散している様子が観察 される。

Table 3に $1500^{\circ} \mathrm{C} て ゙$ 焼もどした試作材に含まれる炭 化物の種類, 体積率および平均粒径を示す. 同表より， $\mathrm{N} \circ 1$ 材, N o 2 材の炭化物は $\mathrm{M}_{7} \mathrm{C}_{3}$ 型で, $\mathrm{N} \circ 3$ 材 のみ $\mathrm{M}_{23} \mathrm{C}_{6}$ 型になっていることがわかる.また $\mathrm{N}$ o 
Table 3 Types, contents and sizes of carbide particles in tested materials.

\begin{tabular}{|c|c|c|c|}
\hline Materials & Type & Content & Mean particle size \\
\hline Steel No.1 & $\mathrm{M}_{7} \mathrm{C}_{3}$ & $18 \%$ & $1.7 \mu \mathrm{m}$ \\
\hline Steel No.2 & $\mathrm{M}_{7} \mathrm{C}_{3}$ & $18 \%$ & $2.0 \mu \mathrm{m}$ \\
\hline Steel No.3 & $\mathrm{M}_{23} \mathrm{C}_{6}$ & $20 \%$ & $2.2 \mu \mathrm{m}$ \\
\hline
\end{tabular}

3 材の炭化物は含有量が $20 \%$, 平均粒径が $2.2 \mu \mathrm{m}$ で, No 1 材に比べ, 含有量で約 $10 \%$, 平均粒径で約 $30 \%$ 大きいこともわかる .

\section{1 .3 抗折試験}

試作粉末材の抗折試験結果をFig.4に示す. 同図より No 1 材〜 N o 3 材ともに抗折值が $3000 \mathrm{MP}$ a を 超える高靬性材であることがわかる.なお, N o 2 材の 抗折值が No 1 材, No3材に比べ低いのは, Photo.1 で観察されたように, 炭化物の形状が異形状のためと 思われる .

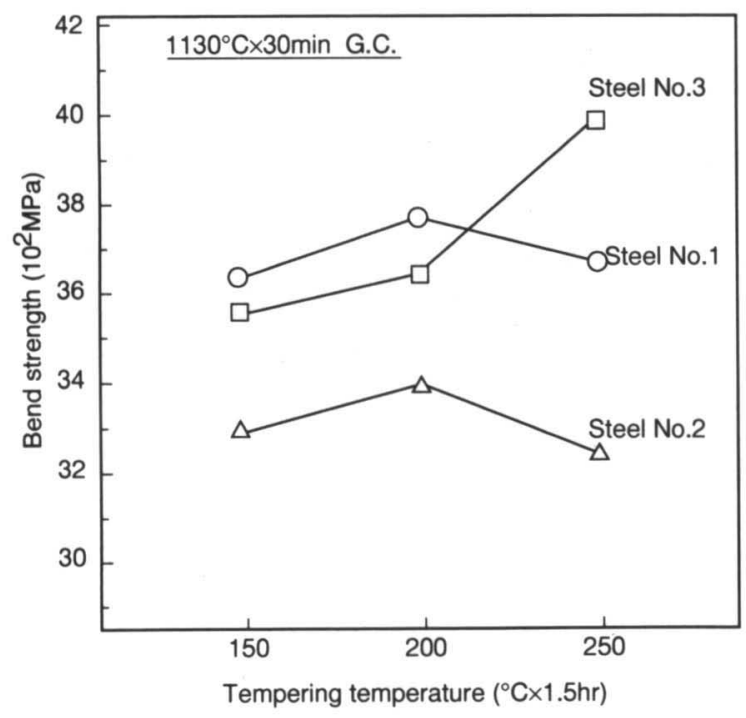

Fig.4 Bend strength.

\subsection{4 水道水浸漬試験}

24 時間の水道水浸漬試験結果をPhoto. 2 に示す. 試 作材（No 1 材〜 No 3 材）およびSU 440 Cに は錆の発生は認められない.一方, KHA 32 (粉末高 速度鋼）では, 試験片のほぼ全面が孔食による腐食生 成物で覆われている様子が観察される.これより, 試作 材はSUS 440 C とほほ同程度の耐食性を有してい ると思われる .

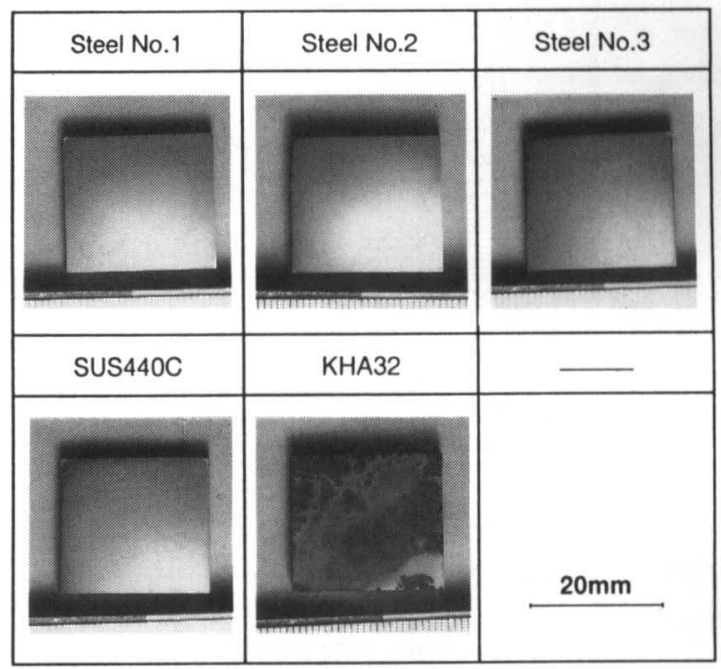

Photo.2 Specimens after $24 \mathrm{hr}$ immersion in water.

\section{1 .5 塩水噴霧試験}

7 時間の塩水噴霧試験結果をPhoto.3 と Fig.5に示す. 写真では孔食痕が明瞭に観察される. 孔食痕の数はN o 2 材, N o 3 材で比較的少なく, 次いでN o 1 材, S US 440 C と徐々に増加し, KHA 32 では無数に 観察される. No 2 材, $\mathrm{N} \circ 3$ 材の孔食痕数が $\mathrm{N} \circ 1$ 材 に比べて少ないのは, 両材の $\mathrm{Mo}$ 含有量が $2 \sim 4 \%$ と 高く，一般に言われているMoの孔食発生の抑制効果 によるものと考えられる5).

Fig. 5 は 7 時間塩水噴霧後の腐食減量を示すもので, $\mathrm{N} \circ 1$ 材〜 No 3 材の耐食性がいずれも，溶製ステン

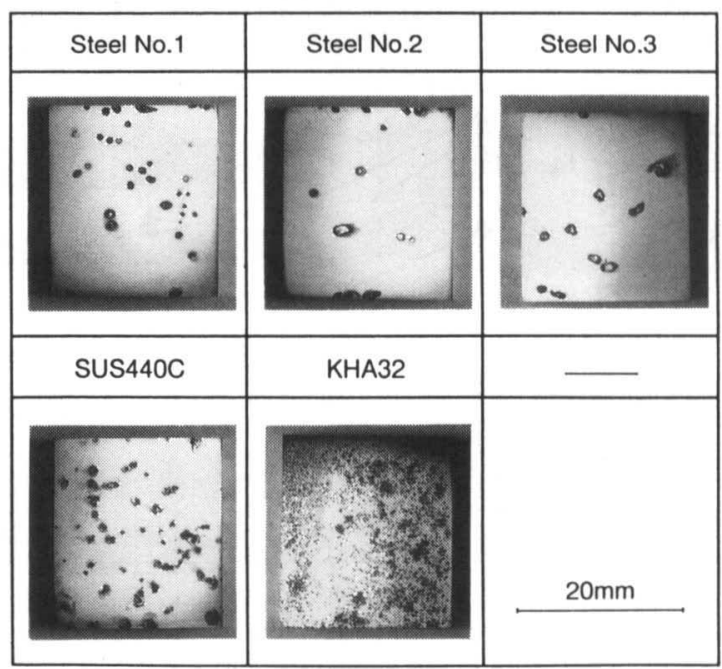

Photo.3 Specimens after 7 hr salt spray. 


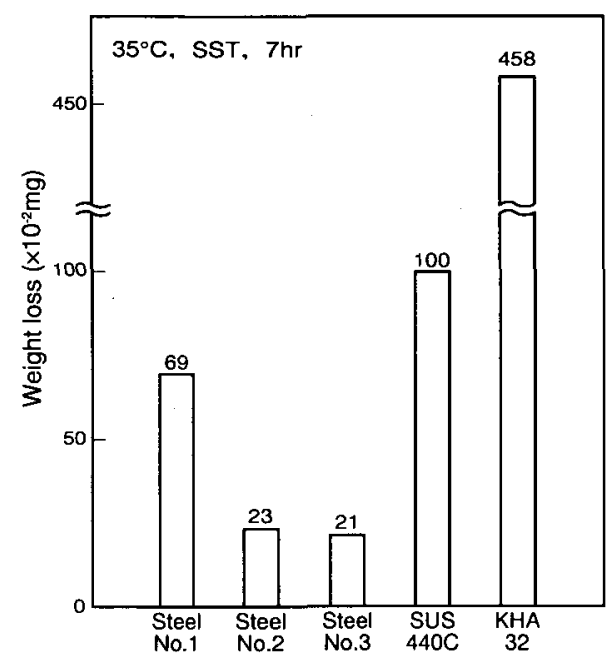

Fig.5 Salt spray test results (7hrs).

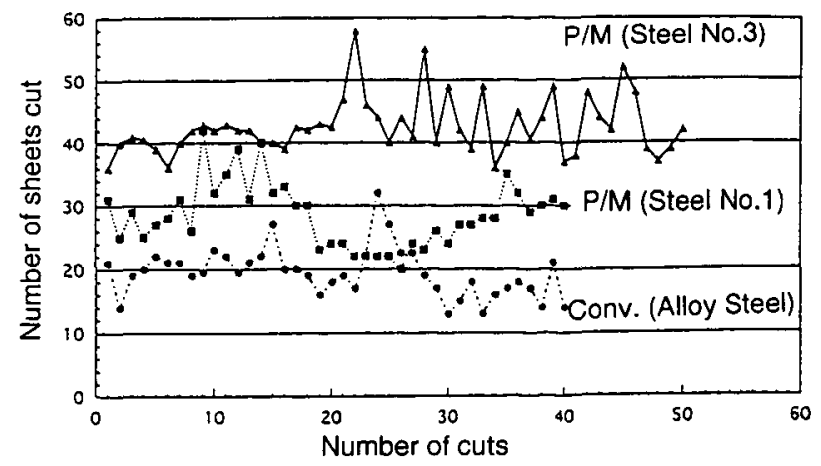

Fig.6 Sharpness test result (Sashimi knife).

くい (3)研ぎやすい との評価を得ており,引き続き ユーザテストを実施中である．

\section{4 結言}

本研究の結果,従来にない耐食耐磨耗性を兼坟備え たステンレス刃物鋼が開発された。とくに試作N o 3 材は, 耐食性で, 耐食性ステンレス刃物として沉用され ているSUS 440 Cに比べ，4〜5倍の耐食性を有 するぼかりでなく，切れ味性においても，高級包丁とし て多用されている従来品の 2 倍以上の切れ味を長時間 持続することが確詔された.同材を「PM21」と命 名し，現在新潟県下で商品化が進められている。

\section{謝 辞}

本研究は, 新潟県の平成 7 年度地元大学との連携機 能強化事業として, 著者らおよび長岡技術科学大学教 授; 武藤睦治, 新潟大学名誉教授; 古川徹, 株坂源社 長; 坂井源一，株タダフサ社長 ; 兽根忠一郎, ナシモ 卜工業社長; 梨本正貫等が㙝力して実施した研究工事 の一部であり，発表の機会を与えてくださった関係各 位に感謝の意を表します。

\section{文献}

1）鴨下隆志, 矢野宏: ツールエンジニア, (1982) 108.

2) 新持喜一郎: 改定 5 版鋼の熱処理, (1969) 521.

3）加藤俊男 : ステンレス , 2 (1982) 13.

4）榎阪肇，今池幸仁，小井川章: 神戸製鋼技報， 3 (1991) 131 .

5）松下幸雄,藤田利夫, 谷野満: 鉄銅の諸性質に及ほ す合金元素の影響 上, (1966) 575. 